Gut, 1977, 18, 377-381

\title{
Immunohistochemical identification of lysozyme in intestinal lesions in ulcerative colitis and Crohn's disease
}

\author{
M. KLOCKARS ${ }^{1}$, S. REITAMO, J. J. REITAMO, AND C. MÖLLER \\ From the Fourth Department of Medicine and Fourth Department of Surgery, Helsinki University \\ Central Hospital, Helsinki, Finland
}

SUMMARY Lysozyme (LZM) was identified in ulcerative colitis in granulocytes, monocytes, and macrophages of the intestinal lamina propria. In contrast with findings in normal colon or rectum, in ulcerative colitis LZM was also detected in some mucosal crypt cells and metaplastic Paneth cells. In both ulcerative colitis and Crohn's disease LZM was present in inflammatory cells of crypt abscesses. In Crohn's disease intense LZM staining was seen in epitheloid cell granulomas. The present observations permit one explanation for the raised concentration of serum-LZM in patients with ulcerative colitis and Crohn's disease.

In inflammatory bowel disease the differential diagnosis as well as the evaluation of specific morphological, chemical, and histochemical indices still present serious difficulties. The recent proposal by Falchuk et al. (1975a) that changes in the concentration of a specific serum marker-namely, lysozyme (LZM)-might be an aid in the differential diagnosis of uncomplicated ulcerative colitis and active Crohn's disease has been questioned by a number of authors (Dronfield and Langman, 1975; Peeters et al., 1975; Pounder et al., 1975; Pruzanski and Marcon, 1975; Hylander et al., 1976; Johansson and Ursing, 1976). However, the determination of the serum concentration of LZM has been reported to be of value in estimating disease activity in Crohn's disease (Falchuk et al., 1975b). An increased LZM content has been observed in the colonic exudates and stools of patients with ulcerative colitis (Hiatt et al., 1952). This variation in the serum and stool LZM concentration has been attributed to the increased number of LZM-containing cells in the inflammatory intestinal lesions. Recently, Mason and Taylor (1975), using an immunoperoxidase technique, detected LZM positive histiocytes in granulomas of the bowel affected by Crohn's disease.

The present study was undertaken to investigate,

\footnotetext{
${ }^{1}$ Address for correspondence: Dr Matti Klockars, Fourth Department of Medicine, Unioninkatu 38, 00170 Helsinki 17, Finland.
}

Received for publication 19 November 1976 with immunohistochemical techniques, the distribution of LZM-containing cells in the intestinal lesions of patients with ulcerative colitis and Crohn's disease.

\section{Methods}

Fifteen patients with ulcerative colitis, seven patients with Crohn's disease, and 24 control patients were studied (Table). Intestinal biopsies were taken either at the surgical resection of affected segments of the small or large bowel. The diagnosis in these cases was based on typical clinical, radiological, and morphological findings. Biopsies were also obtained from the normal small and large intestines of control patients operated on for a disease other than an acute or chronic inflammatory bowel disease, most often for a localised carcinoma of the colon.

The biopsy specimens, none larger than $2 \mathrm{~mm}$ in thickness, were fixed in $1.5 \%$ aqueous glutaraldehyde (TAAB Laboratories, Reading) for 90 minutes, dehydrated in absolute ethanol and xylene, and then embedded in paraffin. Paraffin sections were cut to $6 \mu \mathrm{m}$ in thickness, deparaffinised and rehydrated, and then washed in $0.01 \mathrm{M}$ phosphate-buffered saline (PBS), pH 7.2, twice for five minutes each time. The presence of LZM in tissues was demonstrated with an immunoglobulin-enzyme bridge method (Mason et al., 1969) described in detail elsewhere (Klockars and Reitamo, 1975). Briefly, 
this technique consists of the sequential application, first, of the following antisera: (1) rabbit antihuman LZM, (2) sheep antirabbit gamma globulin (Sycco Sylvana, N.J.), and (3) rabbit antihorseradish peroxidase. After each application of antiserum the sections were washed with PBS twice for five minutes each time. After incubation in horseradish peroxidase at a concentration of $250 \mu \mathrm{g} / \mathrm{ml}$ the sections were stained with the method of Graham and Karnovsky (1966) and then counterstained with cresyl echt violet. To abolish the intrinsic peroxidase activity of granulocytes and erythrocytes, sections were pretreated with methanol- $\mathrm{H}_{2} \mathrm{O}_{2}$ (Streefkerk, 1972). For control of the specificity of the reaction between tissue LZM and the primary antiserumthat is, rabbit antihuman LZM-this antiserum was replaced by a rabbit antiserum raised against hen egg white LZM, known to be immunologically different from its human counterpart.

\section{Results}

\section{CONTROL SUBJECTS}

In the normal ileum LZM was present only in the Paneth cells of the intestinal crypts and in granulocytes and macrophages in the intestinal lamina propria. In normal colon no LZM was detected in surface epithelial cells or in mucous crypt cells, nor was LZM present in the lamina propria except in a few granulocytes. Normal rectum contained no LZM-positive cells (Table).

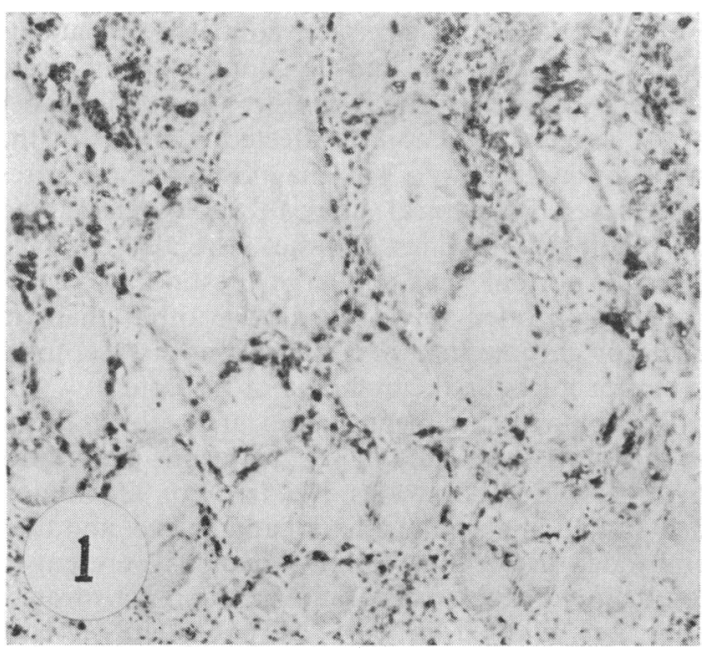

Fig. 1 Colonic mucosa in ulcerative colitis. The LZM is seen as a black precipitate in the inflammatory cells of the lamina propria; no LZM staining is seen in mucosal crypt cells. Counterstaining with cresyl echt violet, $\times 220$.

\section{ULCERATIVE COLITIS}

In the colon and rectum of patients with ulcerative colitis, LZM staining was most prominent in the numerous invading inflammatory cells of the lamina propria (Fig. 1), with intense staining seen predominantly in granulocytes but also in monocytes and macrophages. Colonic surface epithelial cells were LZM negative. However, in three out of five colonic specimens, and in four out of 10 rectum specimens the cytoplasm of occasional mucosal crypt cells, displayed clear LZM staining (Table). This staining was most often diffuse but in a few cells granular (Fig. 2) and in some colonic crypt cells the cytoplasmic morphology and LZM staining was identical with that in the ileal Paneth cells (Fig. 2).

Table Occurrence of immunohistochemically detectable lysozyme in rectal and colonic epithelial cells.

\begin{tabular}{llll}
\hline Condition & $\begin{array}{l}\text { Region of } \\
\text { intestine }\end{array}$ & $\begin{array}{l}\text { Patients } \\
\text { (no.) }\end{array}$ & $\begin{array}{l}\text { Positive } \\
\text { lysozyme } \\
\text { staining }\end{array}$ \\
\hline Controls & Colon & 11 & 0 \\
& Rectum & 13 & 0 \\
Ulcerative colitis & Colon & 5 & 3 \\
Crohn's disease & Rectum & 10 & 4 \\
& Colon & $2^{*}$ & 0 \\
\hline
\end{tabular}

*In one patient biopsies were obtained from both sites.

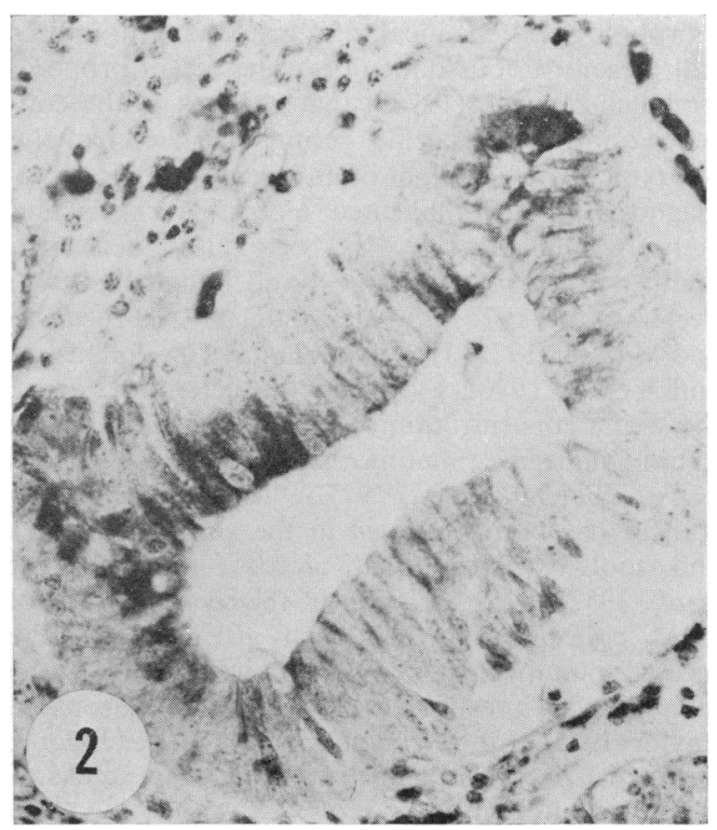

Fig. 2 Cytoplasmic LZM staining in mucosal crypt cells and in inflarmatory cells of the lamina propria in ulcerative colitis. In the upper part of the mucosal gland, LZM-positive Paneth cells can be seen. Counterstaining with cresyl echt violet, $\times 560$. 
LZM staining of the colonic epithelial cells or metaplastic Paneth cells was not related to the number of infiltrating inflammatory cells but could also be seen in areas of quiescent colitis. In the colon of one patient, numerous LZM-positive granulocytes were seen in diapedesis between epithelial cells.

\section{CROHN'S DISEASE}

LZM-positive granulocytes and monocytes were present in numerous microabscesses along the intestinal wall (Fig. 3). Most cells of epitheloid granulomas stained intensely for LZM (Fig. 4). In one patient some mucosal crypt cells stained for LZM (Table). Lymphoctyes, plasma cells, and fibrous tissue showed no LZM staining.

\section{Discussion}

In normal conditions about $80 \%$ of the total pool of LZM is thought to be of granulocyte origin (Hansen, 1974), and in some tissues the concentra-

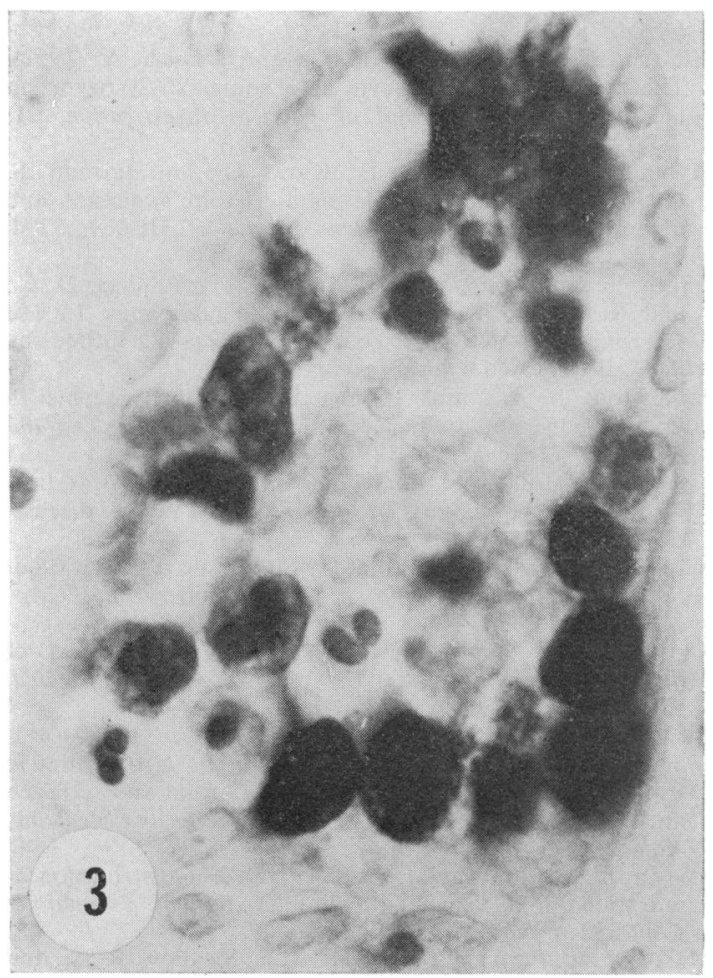

Fig. 3 Numerous LZM-positive polymorphonuclear and mononuclear inflammatory cells in microabscesses of ileal mucosa in Crohn's disease. Observe the absence of lysozyme and endogenous peroxidase staining of binuclear eosinophils, $\times 1000$.

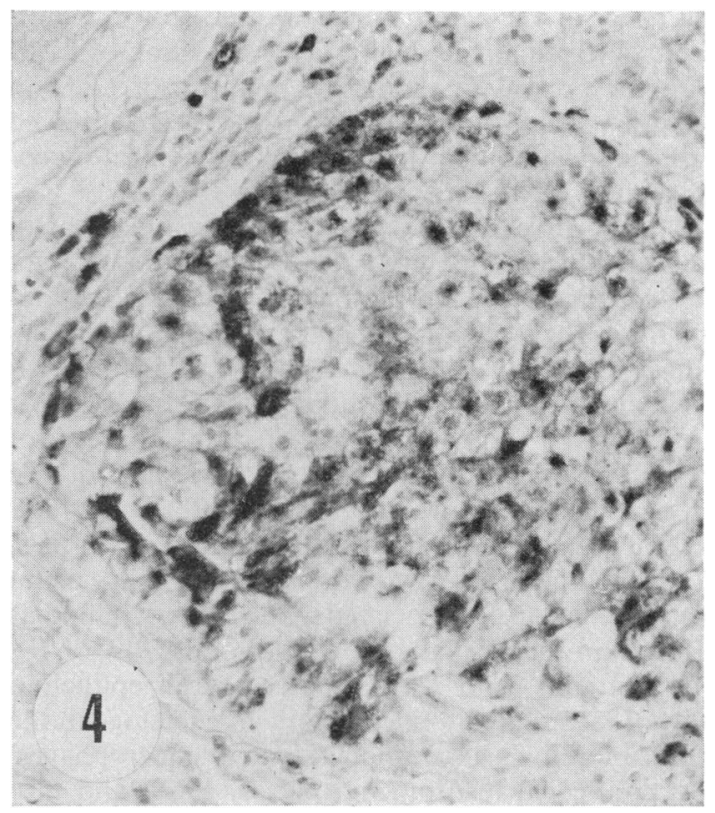

Fig. 4 LZM-positive histiocytes in an epitheloid cell granuloma of the ileal mucosa in Crohn's disease, $\times 220$.

tion of LZM is related to the number of granulocytes, monocytes, and macrophages (Lippman and Finch, 1972; Klockars and Reitamo, 1975). In both ulcerative colitis and Crohn's disease, affected lesions of the intestine contained large numbers of LZMpositive cells, which provides at least one explanation for raised concentrations of plasma LZM in patients with these disorders (Kane et al., 1974; Dronfield and Langman, 1975; Falchuk et al., 1975; Pounder, et al., 1975). That both the total vitamin $\mathrm{B}_{12}$-binding capacity and the LZM activity of serum are increased in these disorders might indicate that the pool of granulocytes is enlarged and their turnover accelerated (Kane et al., 1974).

In many patients with ulcerative colitis and in one patient with Crohn's disease, the presence of LZM in occasional gland cells, although not contributory to the raised levels of serum LZM, contrasts with the absence of LZM of normal colonic mucosa. The LZM in these cells might be a consequence of (1) a transformation of colonic mucosal cells to a cell type with either the capacity to synthesise LZM or reabsorb LZM from its surroundings or (2) of an altered composition of mucosubstances within these cells. The occurrence of neutral mucosubstances in rectal columnar cells in some cases of ulcerative colitis (Gad, 1969) might eliminate a possible block- 
ing effect of the acidic mucosubstances on the antigenic determinants critical for the detection of LZM with the present method. The presence of LZM in secretory cells in normal organs has been observed to be associated with the presence of neutral mucosubstances (Klockars and Reitamo, 1975).

The occurrence of typical LZM-positive Paneth cells in mucosal glands adjacent to mucosal crypt cells with positive cytoplasmic granular LZM staining raises the question of whether a transition occurs between mucous gland cells and Paneth cells (Watson and Roy, 1960; Paterson and Watson, 1961; Lewin, 1969). Whereas the origin and 'stem cell' of Paneth cells is still unknown, the results of the present study support the possibility that glandular cells of the mucosa are transformed into Paneth cells. Our preliminary observations show that metaplastic Paneth cells associated with gastric carcinomas also retain their capacity to elaborate LZM.

In patients with Crohn's disease the epitheloid cells of intestinal granulomas are an end stage in the transformation of monocytes and macrophages. Morphological (Sutton and Weiss, 1966) and biochemical studies (Cohn and Benson, 1965) show that both the number of lysosomes and the concentration of lysosomal enzymes, including LZM, increase during the course of this transformation. Similarly, strong LZM activity has been observed in epitheloid cell granulomas in sarcoidosis and in Kveimpositive subcutaneous nodules (Mason and Taylor, 1975).

Although the findings presented here do not provide any conclusive information about possible differences in serum concentrations of LZM in Crohn's disease and ulcerative colitis (Falchuk et al., 1975a), it is possible that the fate of LZM-containing inflammatory cells and their enzymic content might differ in these diseases. Fixed mononuclear phagocytes may lose their enzymic content into the circulation, whereas the granulocytes in ulcerative colitis might ultimately reach the colonic lumen by diapedesis (Anthonisen and Riis, 1962).

In the absence of any known substrate for LZM in mammalian cells, the physiological consequences of the presence of high local concentrations of LZM might be related to the effects of LZM on cell membranes (Osserman et al., 1973), to its antibacterial effects (Chipman and Sharon, 1969), to its enhancing effect on phagocytosis (Klockars and Roberts, 1976), or to its tendency to form complexes with a variety of anionic molecules (Imoto et al., 1971).

This study was supported by grants from the Finnish National Research Council for Medical Sciences and the Sigrid Jusélius Foundation.

\section{References}

Anthonisen, P., and Riis, P. (1962). The cytology of colonic secretion in proctosigmoidal disease. Acta Medica Scandinavica, 172, 375-381.

Chipman, D. M., and Sharon, N. (1969). Mechanism of lysozyme action. Science, 165, 454-465.

Cohn, Z. A., and Benson, B. (1965). The differentation of mononuclear phagocytes. Morphology, cytochemistry and biochemistry. Journal of Experimental Medicine, 121, 153-169.

Dronfield, M. W., and Langman, M. J. S. (1975). Serum lysozyme in inflammatory bowel disease. Gut, 16, 985-987.

Falchuk, K. R., Perrotto, J.L., and Isselbacher, K. J. (1975a). Serum lysozyme in Crohn's disease and ulcerative colitis. New England Journal of Medicine, 292, 395-397.

Falchuk, K. R., Perrotto, J. L., and Isselbacher, K. J. (1975b). Serum lysozyme in Crohn's disease. A useful index of disease activity. Gastroenterology, 69, 893-896.

Gad, A. (1969). A histochemical study of human alimentary tract mucosubstances in health and disease. 2. Inflammatory conditions. British Journal of Cancer, 23, 64-68.

Graham, R. C., and Karnovsky, M. J. (1966). The early stages of absorption of injected horseradish peroxidase in the proximal tubules of mouse kidney. Ultrastructural cytochemistry by a new technique. Journal of Histochemistry and Cytochemistry, 14, 291-302.

Hansen, N. E. (1974). Plasma lysozyme-A measure of neutrophil turnover. An analytical review. Series Haematologica, 7, 1-87.

Hiatt, R. B., Engle, C., Flood, C., and Karush, A. (1952). The role of the granulocyte as a source of lysozyme in ulcerative colitis. Journal of Clinical Investigation, 31, 721-726.

Hylander, E., Hansen, N. E., Karle, H., and Jarnum, S. (1976). Serum lysozyme levels in Crohn's disease and ulcerative colitis. New England Journal of Medicine, 294, 111.

Imoto, T., Johnson, L. N., Noth, A. C. T., Phillips, D. C., and Rupley, J. A. (1972). Vertebrate lysozymes. In The Enzymes, 3rd edn. pp. 665-868. volume 7. Edited by P. D. Boyer. Academic Press: New York.

Johansson, B. G., and Ursing, B. (1976). Lysozyme in Crohn's disease: influence of methods. New England Journal of Medicine, 294, 337.

Kane, S. P., Hoffbrand, A. V., and Neale, G. (1974). Indices of granulocyte activity in inflammatory bowel disease. Gut, 15, 953-959.

Klockars, M., and Reitamo, S. (1975). Tissue distribution of lysozyme in man. Journal of Histochemistry and Cytochemistry, 23, 932-940.

Klockars, M., and Roberts, P. (1976). Stimulation of phagocytosis by human lysozyme. Acta Haematologica, 55, 289-295.

Lewin, K. (1969). The Paneth cell in disease. Gut, 10, 804-811. Lippman, M. E., and Finch, S. C. (1972). A quantitative study of muramidase distribution in normal and nitrogen mustard-treated rats. Yale Journal of Biology and Medicine, 45, 463-470.

Mason, D. Y., and Taylor, C. R. (1975). The distribution of muramidase (lysozyme) in human tissues. Journal of Clinical Pathology, 28, 124-132.

Mason, T. E., Phifer, R. F., Spicer, S. S., Swallow, R. A., and Dreskin, R. B. (1969). An immunoglobulin-enzyme bridge method for localizing tissue antigens. Journal of Histochemistry and Cytochemistry, 17, 563-569.

Osserman, E. F., Klockars, M., Halper, J., and Fischel, R. E. (1973). Effects of lysozyme on normal and transformed mammalian cells. Nature, 243, 331-335. 
Paterson, J. C., and Watson, S. H. (1961). Paneth cell metaplasia in ulcerative colitis. American Journal of Pathology, 38, 243-249.

Peeters, T. L., Geboes, K., and Vantrappen, G. R. (1975). Serum lysozyme levels in Crohn's disease. New England Journal of Medicine, 292, 1349.

Pounder, R. E., Avella, J. R., McCallum, H., and Misiewicz J. J. (1975). Serum lysozyme in inflammatory bowel disease. Lancet, 2, 228-229.

Pruzanski, W., and Marcon, N. (1975). Lysozyme in Crohn's disease. New England Journal of Medicine, 293, 611-612.
Streefkerk, J. G. (1972). Inhibition of erythrocyte pseudoperoxidase activity by treatment with hydrogen peroxide following methanol. Journal of Histochemistry and Cytochemistry, 20, 829-830.

Sutton, J. S., and Weiss, L. (1966). Transformation of monocytes in tissue culture into macrophages, epithelioid cells and multinucleated giant cells. Journal of Cell Biology, 28, 303-332.

Watson, A. J., and Roy, A. D. (1960). Paneth cells in the large intestine in ulcerative colitis. Journal of Pathology and Bacteriology, 80, 309-316.

\section{The April 1977 Issue}

\section{THE APRIL 1977 ISSUE CONTAINS THE FOLLOWING PAPERS}

Immunofluorescent localisation of enterokinase in Symptomatic significance of gastric mucosal changes human small intestine J. HERMON-TAYLOR, J. after surgery for peptic ulcer A. M. HOARE, E. $L$. PERRIN, D. A. W. GRANT, A. APPLEYARD, M. BUBEL, JONES, J. ALEXANDER-WILLIAMS, AND C. F. HAWKINS

AND A. I. MAGEE

Ischaemic strictures of the small intestine in Nigeria S. G. SUBBUSWAMY AND F. I. IWEZE

Intestinal alkaline phosphatase in the diagnosis of liver disease T. W. WARNES, P. HINE, AND G. KAY

Activation and release of proteolytic kinin-forming enzymes from rat jejunal loops perfused with hyperosmolar glucose solutions $\quad K$. J. WORTHINGTON AND A. CUSCHIERI

Rectal potential difference and histology in Crohn's disease W. S. J. RUDDELL, L. M. BLENDIS, AND D. LOVELL

Enzymatic and morphometric evidence for Crohn's disease as a diffuse lesion of the gastrointestinal tract W. T. DUNNE, W. T. COOKE, AND R. N. ALLAN
A search for volatile nitrosamines in East African spirit T. A. GOUGH

Effect of atropine and proximal gastric vagotomy on the acid response to fundic distension in man $U$. GRÖTZINGER, S. BERGEGÅRDH, AND L. OLBE

Antibodies to pancreatic duct cells in Sjögren's syndrome and rheumatoid arthritis H. LUDWIG, G. SCHERNTHANER, O. SCHERAK, AND G. KOLARZ

\section{Progress report ERCP}

Notes and activities

Books

Copies are still available and may be obtained from the PUBLISHING MANAGER, BRITISH MEDICAL ASSOCIATION, TAVISTOCK SQUARE, LONDON WC1H 9JR, price $£ 2 \cdot 75$, including postage 